Journal of Animal and Veterinary Advances 9 (24): 3117-3124, 2010

ISSN: $1680-5593$

(C) Medwell Journals, 2010

\title{
Resveratrol Inhibits Invasion and Metastasis of Hepatocellular Carcinoma Cells
}

\author{
${ }^{1} \mathrm{Hai}-\mathrm{Bo}$ Yu, ${ }^{1} \mathrm{De}-\mathrm{Yu} \mathrm{Li},{ }^{2} \mathrm{Hui}-\mathrm{Feng}$ Zhang, ${ }^{1} \mathrm{Huan}-\mathrm{Zhou}$ Xue, ${ }^{3} \mathrm{Cheng}-\mathrm{En}$ Pan, \\ ${ }^{4}$ Si-Hai Zhao and ${ }^{5}$ Lei Wang \\ ${ }^{1}$ Department of Hepatobiliary Surgery of Henan Provincial People's Hospital, Zhengzhou, China \\ ${ }^{2}$ Intensive Care Unit of Henan Provincial People's Hospital, Zhengzhou, China \\ ${ }^{3}$ Department of Hepatobiliary Surgery, The First Affiliated Hospital, \\ Xi'an Jiaotong University, Shaanxi, China \\ ${ }^{4}$ Laboratory Animal Centre, Xi' an Jiaotong University School of Medicine, Shaanxi, China \\ ${ }^{5}$ Department of Biochemistry and Molecular Biology of Henan, University of TCM, Zhengzhou, China
}

\begin{abstract}
Resveratrol (trans-3, 4', 5-trihydroxystilbene) is a natural phytoalexin found in grapes and other plants that has anti-cancer and anti-inflammatory effects. To observe its effects of on proliferation of human hepatocellular carcinoma cells and the underlying molecular mechanisms, we performed the current study. MTT assay was used to assess the effects of resveratrol on proliferation of human hepatocellular carcinoma cell line HepG2. Flow cytometry and invasion assays were performed to detect apoptosis and tumor cell invasion capacity was detected in vitro and in vivo. After that Real-time quantitative PCR and western blotting assays were used to detect the expression of MMP-9 mRNA and protein, respectively. MMP-9 activity was also analyzed by gelatin zymography assay. NF-kappa B was measured by electrophoretic mobility shift assay. Resveratrol inhibited growth of $\mathrm{HepG} 2$ cells with a dose and time-dependent manner. The reduced cell viability is due to apoptosis or proliferation inhibited by resveratrol. Invasion assay found that resveratrol induce a decrease in the potential for invasion. Molecularly, resveratrol was able to reduce both MMP-9 mRNA expression and protein levels as wellas MMP-9 enzymatic activity which may be via the inhibition of NF-kappaB activity. The data showed that resveratrol was able to reduce viability of hepatocellular carcinoma cells which is due to induction of apoptosis by resveratrol. Resveratrol also inhibited tumor cell invasion capacity which is through down regulation of MMP-9 levels and its enzymatic activity. Future study will investigate the effects of resveratrol in vivo in control of hepatocellular carcinoma cell in clinics.
\end{abstract}

Key words: Resveratrol, cell growth, apoptosis, invasion, hepatocellular carcinoma, MMP-9, NF-kappa B

\section{INTRUCTION}

The incidence of Hepatocellular Carcinoma (HCC) is on the rise worldwide as the most common primary hepatic malignancy. Although, many potent anti-cancer drugs can be clinically applicable, the above drugs are generally known to have strong cellular cytotoxicity and side effects. Thus, strong anti-cancer drugs without any cytotoxicity and side effects would be highly desirable. Resveratrol (3, 5, 4'-trihydroxystilbene), a polyphenol found in red wine that is associated with many health benefits, most notably the mitigation of age-related diseases, including neurodegeneration, carcinogenesis and atherosclerosis (Ferguson, 2001; Jang et al., 1997; Middleton et al., 2000). Resveratrol was found to suppress MMP-9 expression of mouse mammary cancer, multiple myeloma, murine bladder cancer and human breast cancer cell (Gunther et al., 2007; Sun et al., 2006; Pozo-Guisado et al., 2005; Mediero et al., 2005). Although, the chemopreventive function on hepatic carcinoma of resveratrol has been well appreciated, the mechanisms by which resveratrol exerts its MMPs inhibition effects remain largely unknown. The present study has been designed to find that resveratrol suppresses MMP-9 gene transcription. Resveratrol inhibited Phorbol Myristate Acetate (PMA)-mediated activation of nuclear factor-kappa $\mathrm{B}$ activation. These data provide a mechanistic basis for the resveratrol on the regulation of MMP-9 protease which has a major role in tumor invasion and metastasis. Invasion and metastasis is fundamental property of malignant cancer cell and the main factors related to the poor prognosis. The main physiologic barriers to the movement of cell into tissues is invasion of tumor cells into the Extracellular Matrix

Corresponding Author: Hai-Bo Yu, Department of Hepatobiliary Surgery, Henan Provincial People's Hospital, No. 7 Weiwu Road, 450003, Zhengzhou, China 
(ECM) and Basement Membrane (BM), so the degradation of ECM and BM is one of the most important step in he process of cancer invasion and metastasis (Vlodavsky and Friedmann, 2001).

Matrix Metalloproteinases (MMPs) are a t-family of enzymes capable of degrading the constituents of ECM and BM which is a crucial step involved in various stages of tumor progression, including tumor angiogenesis, tumor growth and also local invasion and subsequent distant metastasis (Adithi et al., 2007). High MMP levels are associated with poor prognosis in cancer patients (Kader et al., 2007). Therefore, researchers initialed the current study to investigate mechanism of resveratrol inhibit metastasis of hepatocellular carcinoma.

\section{MATERIALS AND METHODS}

Reagents: DMEM, Trizol reagent and calf serum were from GIBCOBRL. M-MLV reverse transcriptase and Taq DNA polymerase were from Invitrogen. Resveratrol and PMA were from Sigma. Goat monoclonal anti-human MMP-9 antibody was from NeoMarker.

Cell culture: A hepatocellular carcinoma cell line HepG2 was obtained from the American Type Culture Collection (ATCC) and grown in DMEM with highglucose $\left(4.5 \mathrm{~g} \mathrm{~L} \mathrm{~L}^{-1}\right)$ and supplemented with $10 \%$ calf serum, 100 units $\mathrm{mL}^{-1}$ penicilin and $100 \mathrm{mg} \mathrm{mL}-1$ streptomycin and sodium bicarbonate $\left(2.0 \mathrm{~g} \mathrm{~L}^{-1}\right)$ at $37^{\circ} \mathrm{C}$ in $5 \% \mathrm{CO}_{2}$.

MTT proliferation assay: Cell proliferation was investigated using MTT (3-[4, 5-dimethylthiazol-2-yl] -2, 5-diphenyltetrazolium bromide, a tetrazolium salt) assay. HepG2 cells were subcultured into 96 well culture plates at a density of $5 \times 10^{3}$ cells well $^{-1}$ in $200 \mu \mathrm{L}$ of DMEM culture medium. After $24 \mathrm{~h}$ of incubation, the medium in the 96 well plate was discarded and replaced with $200 \mu \mathrm{L}$ of new medium containing various concentrations of resveratrol. The plates were incubated in a $37^{\circ} \mathrm{C}$ humidified incubator in an atmosphere of $5 \% \mathrm{CO}_{2}$ for 24 , 48 and $72 \mathrm{~h}$. At the end of the incubation, $20 \mu \mathrm{L}$ of MTT test solution was added and incubated in a $37^{\circ} \mathrm{C}$ and $5 \%$ $\mathrm{CO}_{2}$ incubator for $4 \mathrm{~h}$. After $4 \mathrm{~h}$ of incubation, absorbance was measured on an ELISA reader at a test wavelength of $490 \mathrm{~nm}$.

Animal treatment: $\mathrm{BALB} / \mathrm{c}(\mathrm{nu} / \mathrm{nu})$ nude mice $(6$ weeks of age) were supplied from the Experimental Animal Center of the Fourth Military Medical University. The animals were housed in climate-controlled quarters $\left(24 \pm 1^{\circ} \mathrm{C}\right.$ at $50 \%$ humidity) with a $12 \mathrm{~h}$ light/12 h dark cycle. HepG 2 cells were harvested from tissue culture flasks with trypsin treatment. The cells were then washed with serum-free medium and suspended at a concentration of $5 \times 107 \mathrm{~mL}^{-1}$ in serum-free medium. About $200 \mu \mathrm{L}$ suspension containing 107 cells was injected subcutaneously into the right flank of nude mice. To evaluate the effect of resveratrol on tumor growth and liver metastasis, treatment of the drugs was carried out by subcutaneous administration. For subcutaneous administration of the drugs, experimental animals ( $\mathrm{n}=10$ for each group) were treated with 50 and $100 \mu \mathrm{g} \mathrm{kg}^{-1}$ resveratrol three times per week beginning on the day of tumor cell implantation. Control mice were treated with normal saline $(0.9 \%)$. Tumor volume was determined by measuring tumor size with calipers as resveratrol administration. All of the mice were killed 21 days after tumor implantation.

Analysis of apoptosis by flow cytometry: HepG2 stimulated with PMA (100 nM) for $24 \mathrm{~h}$ were washed and incubated with fresh serum-free medium containing 0,50 , 100 and $200 \mu \mathrm{M}$ resveratrol for $24 \mathrm{~h}$. Cells were harvested, centrifuged at $1500 \mathrm{rpm}$ for $10 \mathrm{~min}$, washed with PBS and incubated with a fluorescein isothiocyanate-labeled annexin $\mathrm{V}$ antibody. The labeled cells were analyzed by flow cytometry. Cells were also stained with Propidium Iodide (PI). Percentages of cells with positive stain for annexin $\mathrm{V}$ and PI were determined. Apoptotic cells were analyzed by flow cytometry as above.

Invasion assay: Millicell ( $12 \mu \mathrm{M}$ pore size $)$ with Matrigel that fit into 24 well invasion chambers were obtained from Millipore. HepG2 cells to be tested for invasion were detached from the $25 \mathrm{~cm}^{2}$ flasks, washed, resuspended in conditioned medium with different concentration resveratrol $\left(2 \times 10^{5}\right.$ cells $\left./ 200 \mu \mathrm{L}\right)$ and added to the upper compartment of the invasion chamber. About $500 \mu \mathrm{M}$ conditioned medium with $10 \%$ FCS was added to the lower compartment of the invasion chamber. The Millicell invasion chambers were incubated at $37^{\circ} \mathrm{C}$ for $24 \mathrm{~h}$ in $5 \%$ $\mathrm{CO}_{2}$. After incubation, filter inserts were fixed, stained and removed from the wells and the cells on the upper side of the filter were removed using cotton swabs. The cells that invaded through the Matrigel and were located on the underside of the filter were counted. Three invasion chambers were used per concentration. The values obtained were calculated by averaging the total number of cells from three filters.

\section{Reverse Transcription Polymerase Chain Reaction} (RT-PCR): Total RNA was isolated from HepG2 cell line with Trizol reagent and quantitated by UV absorption. After reverse transcription of $2 \mathrm{ug}$ with oligo (dT) priming by $\mathrm{M}-\mathrm{MLV}$ reverse transcriptase, the resulting singlestranded cDNA was amplified using $2 \times$ TaqDNA PCR Master Mix. The polymerase chain reaction parameters for MMP-9 and GAPDH were as following primers: MMP-9 (328 bp) sense 5' TCC CTG GAG ACC TGA GAA CC 3', antisense 5' CGG CAA GTC TTC CGA GTA GTT 3'; 
GAPDH (527 bp) sense 5'-TCC TGC ACC ACC AAC TGC TT-3' antisense 5'-TCC ACC ACC CTG TTG CTG TA-3'. PCR products were separated by $1.5 \%$ agarose gel electrophoresis and visualized by ethidium bromide staining and quantified by a complete gel document and analysis system. The mRNA expression level was determined by the ratio of objective genes and GAPDH.

Protein extraction and Western blotting assay: Cells grown in $25 \mathrm{~cm}^{2}$ flasks were lysed in RIPA lysis buffer [50 Mm Tris ( $\mathrm{pH}$ 7.4), $150 \mathrm{mM} \mathrm{NaCl}, 1 \%$ Tritonx- $100,1 \%$ sodium deoxycholate, $0.1 \% \mathrm{SDS}, 5 \mathrm{mMEDTA}, 10 \mu \mathrm{g} \mathrm{m} \mathrm{m}^{-1}$ aprotinin, $10 \mu \mathrm{g} \mathrm{mL}^{-1}$ leupeptinin] and cocktail proteinase inhibitor. Cell lysates were incubated on ice for $30 \mathrm{~min}$ and then spum down at $15000 \mathrm{rpm}$ for $15 \mathrm{~min}$ at $4^{\circ} \mathrm{C}$. The protein concentrations were quantitated by $\mathrm{BCA}$ protein assay kit. Equal amounts of $50 \mu \mathrm{g}$ proteins were loaded onto a $10 \%$ polyacrylaminde-SDS gel. After electrophoreses, the protein were transferred onto a nitrocellulose membrane. Membrane were blocked and probed with mouse anti human monoclonal MMP-9 antibody in 5\% nonfat dried milk with a solution of TBS containing $0.05 \%$ Tween- 20 overnight. After $30 \mathrm{~min}$ washes in TBS- $0.05 \%$ Tween-20, blots were incubated with horseradish peroxidase-conjugated secondary antibodies for $60 \mathrm{~min}$ followed by $30 \mathrm{~min}$ washes in TBS-0.05 Tween-20. Immunoreactive bands were detected using the enhanced chemiluminescence system after exposure of the membrane to film for $30-60 \mathrm{sec}$.

Gelatin zymography: Gelatin zymography was used for the analysis of MMPs in culture medium as described previously. Briefly, cells seeded in $25 \mathrm{~cm}^{2}$ flasks and cultured in complete medium as above. When up to 60-70\% confluent, cells were maintained in $5 \mathrm{~mL}$ lowglucose DMEM with $1 \%$ serum for $24 \mathrm{~h}$. Then the cells were induced by $100 \mathrm{nM}$ PMA for $24 \mathrm{~h}$ and at the end of time various concentrations of resveratrol in serum-free medium for $24 \mathrm{~h}$. After which the medium was colleted and concentrated 5 fold by freeze-drying before analysis. Aliquots of the conditioned medium were separated on a $10 \%$ polyacrylamide-SDS gel with $1 \mathrm{mg} \mathrm{mL}{ }^{-1}$ gelatin (Sigma, USA) under nondenaturing conditions. After electrophoresis, the gels were incubated in $2.5 \%$ Triton $\mathrm{x}-100$ for $2 \mathrm{~h}$ to remove the SDS and subsequently incubated for $42 \mathrm{~h}$ in substrate buffer $(50 \mathrm{mM}$ Tris-Hcl, $5 \mathrm{mM} \mathrm{CaCl}_{2}, 1.0 \mu \mathrm{M} \mathrm{ZnCl}_{2}$ and $0.02 \% \mathrm{NaN}_{3}, \mathrm{pH} 7.5$ ) at $37^{\circ} \mathrm{C}$. Gels were stained in a solution containing $0.05 \%$ Coomassie Blue R-250, 30\% methanol and 10\% acetic acid for $1 \mathrm{~h}$ and destained in a solution of $30 \%$ methanol and $10 \%$ acetic acid to put into evidence clear bands of gelatinolytic activity on a blue background. Proteinase was identified on the basis of their molecular weight and using low molecular protein standards run in parallel with samples.
Electrophoresis Mobility Shift Assay (EMSA): HepG2 cells were washed twice with D-Hanks' balanced salt solution, resuspended in $400 \mu \mathrm{L}$ Buffer A (HEPES $10 \mathrm{mmol} \mathrm{L}^{-1}, \mathrm{KCl} 10 \mathrm{mmol} \mathrm{L}^{-1}$, DTT $1 \mathrm{mmol} \mathrm{L}^{-1}$, EDTA $0.1 \mathrm{mmol} \mathrm{L}^{-1}$, EGTA $0.1 \mathrm{mmol} \mathrm{L}^{-1}$ ) with buffer $\mathrm{C}$ (Aprotinin $0.1 \mathrm{mg}$, Leupeptin $0.1 \mathrm{mg}$, Pepstatin $0.05 \mathrm{mg}$, PMSF $5 \mathrm{mM}$ ) and incubated on ice for $15 \mathrm{~min}$. Then the cell lysates were severily shocked with $25 \mu \mathrm{L} \quad 10 \% \mathrm{NP}-40$ for $30 \mathrm{sec}$ and spum down at $12000 \mathrm{rpm}$ for $15 \mathrm{~min}$ at $4^{\circ} \mathrm{C}$. After centrifugation, nuclei were shocked with Buffer B (HEPES $20 \mathrm{mmol} \mathrm{L}^{-1}, \mathrm{KCl} 400 \mathrm{mmol} \mathrm{L}^{-1}$, DTT $1 \mathrm{mmol} \mathrm{L}^{-1}$, EDTA $0.1 \mathrm{mmol} \mathrm{L}^{-1}$, EGTA $0.1 \mathrm{mmol} \mathrm{L}^{-1}$ ) and buffer $\mathrm{C}$ for $45 \mathrm{~min}$. The nuclear extract was then centrifuged at $12000 \mathrm{rpm}$ for $15 \mathrm{~min}$ at $4^{\circ} \mathrm{C}$. Supernatants were collected and stored at $-70^{\circ} \mathrm{C}$ for later use. Oligonucleotides used for the gel shift analysis were as follows: NF-kappa B (5'-AGT TGA GGG GAC TTT CCC AGG C-3, 5'-TCA ACT CCC CTG AAA GGG TCC G-3'). Nuclear extracts were incubated with 32P-labeled oligonucleotides, solved on non-denaturing $8 \%$ polyacrylamide gel and visualized by autoradiograph.

Statistical analysis: Results were presented as mean \pm SD . Statistical significance was analyzed by t-test. The value of $\mathrm{p}<0.05$ is considered significant.

\section{RESULTS AND DISCUSSION}

Effect of resveratrol on cell viability: To evaluate the effects of resveratrol on hepatoma, HepG2 cells were explosed to resveratrol at different time points and doses. The cell viability was measured by using an MTT assay.

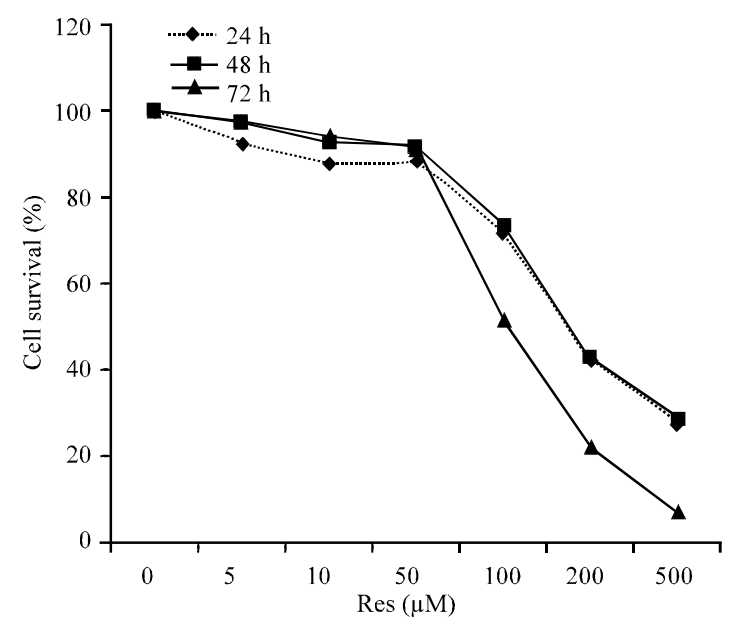

Fig. 1: Resveratrol inhibits the proliferation of HepG2. Effect of different concentrations of resveratrol on the proliferation of $\mathrm{HePG} 2$ incubated for 24, 48 and $72 \mathrm{~h}$. The data are presented as the mean plus/minus SE $(n=4)$ 

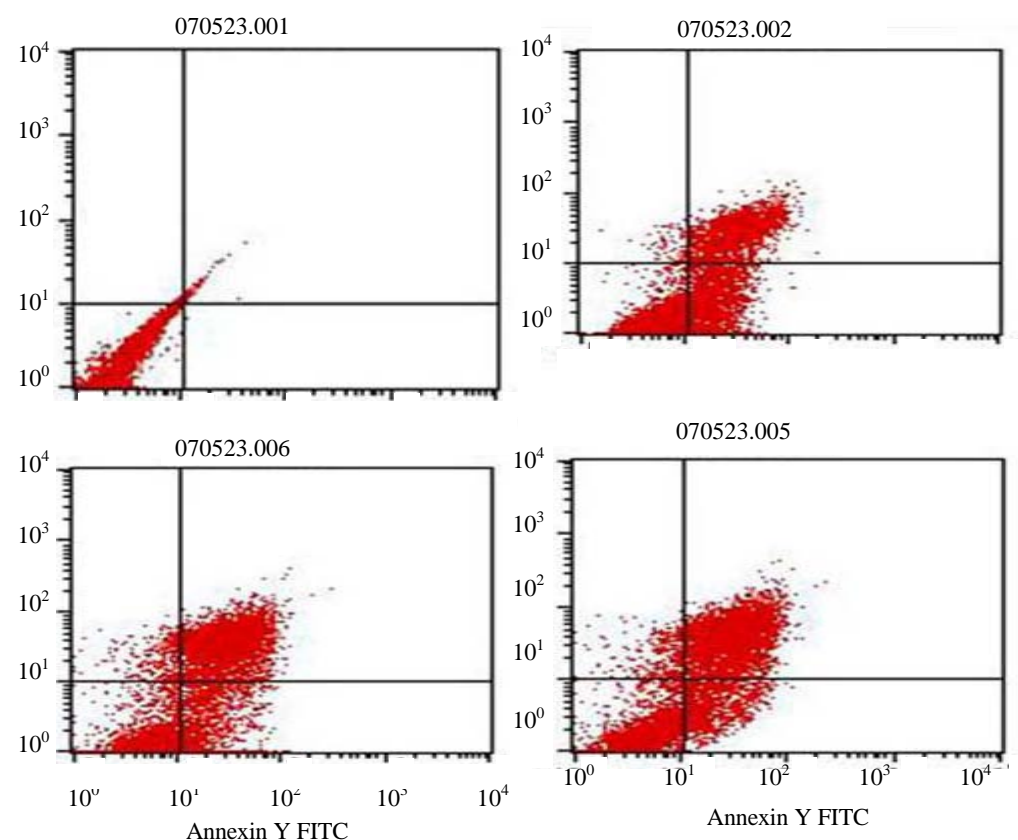

(b)

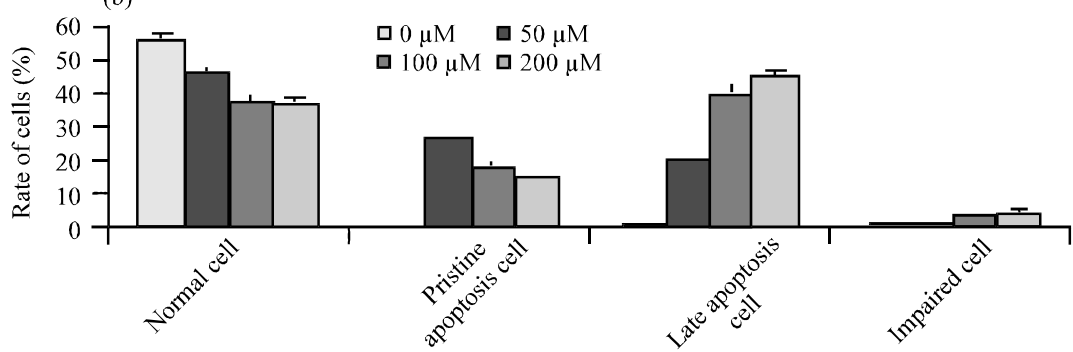

Fig. 2: Determination of cell apoptosis by flow cytometric analysis of annexin V and PI positive HepG2 treated with $100 \mathrm{nM}$ PMA for $24 \mathrm{~h}$; (a) Representative flow cytometry graphs. Cells were treated with different concentration resveratrol: control (UL), $50 \mu \mathrm{M}$ (UR), $100 \mu \mathrm{M}$ (LL) and $200 \mu \mathrm{M}$ (LR) and (b) mean percentage of cells stained with annexin $\mathrm{V}$ and $\mathrm{PI}$. Each bar represents mean $\pm \mathrm{SD}$ of three experiments, $\mathrm{p}<0.05$ vs control

The data showed that resveratrol had a dosedependent effect on the growth of HepG 2 cells. The addition of $200 \mu \mathrm{M}$ of resveratrol reduced cell viability obviously compared to the control group after $24 \mathrm{~h}$. In Fig. 1, the data show that resveratrol also has a timedependent effect on HepG2 cells after 24, 48 and $72 \mathrm{~h}$ treatment.

The reduced cell viability by resveratrol due to induction of apoptosis or cell proliferation: We tested cell apoptosis by adding increasing concentrations of resveratrol to HepG2 stimulated with $100 \mathrm{nM}$ PMA for $24 \mathrm{~h}$ and analyzed annexin V and PI-positive cells by flow cytometry. With a concentration-dependent increase apoptosis cells increased (Fig. 2). There was obvious significant increase in annexin V and PI-positive HepG2 cells treated with resveratrol at 50,100 and $200 \mu \mathrm{M}$ corresponded to control group $(\mathrm{p}<0.05)$.
Effect of resveratrol on in vitro invasion of HepG2 cells: An inhibitory effect of resveratrol on the invasion of PMA-induced HepG2 cells in vitro was evidenced by a Matrigel invasion assay. As shown in Fig. 3, the invasiveness of resveratrol on PMA-induced HepG2 cells was decreased when compared with the invasiveness of PMA-untreated HepG2 cells ( $\mathrm{p}<0.05$ ). From this result, we concluded that resveratrol induced a decrease in the potential for invasion.

Inhibitory effect of resveratrol on tumor growth in mice: To investigate the effect of resveratrol on tumor growth in vivo, HepG2 cells were injected subcutaneously into the right flank of nude mice ( 6 weeks old). Experimental animals ( $\mathrm{n}=10$ each group) were treated with resveratrol ( 50 and $100 \mathrm{mg} \mathrm{kg}^{-1}$ ) every 2 days beginning on the day of tumor formation. As shown in Table 1, tumor size showed a significant reduction in the $50 \mathrm{mg} \mathrm{kg}^{-1}$ 
(a)

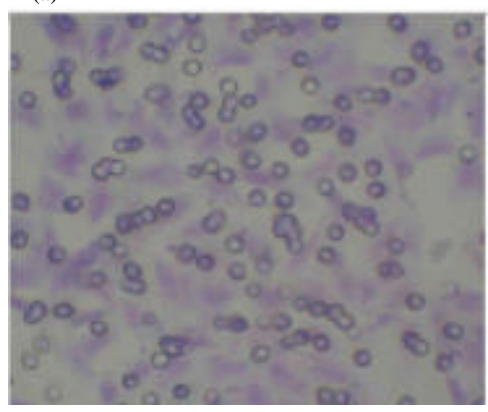

PMA $200 \mathrm{nM}$

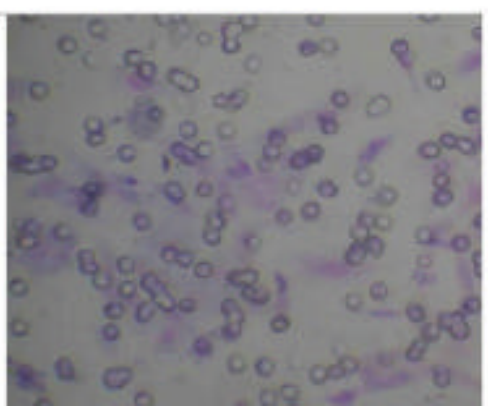

PMA $200 \mathrm{nM}+\operatorname{Res} 100 \mu \mathrm{M}$

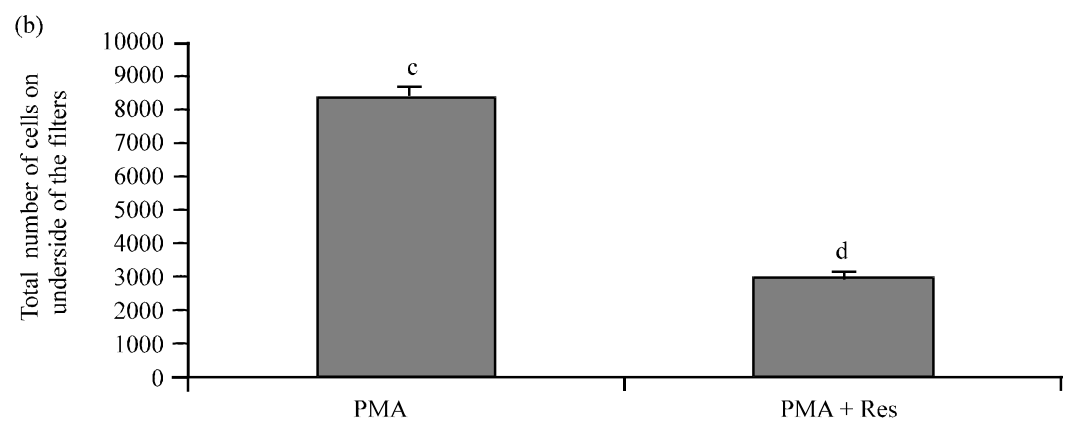

Fig. 3: Effect of resveratrol on matrigel invasion by HepG2 cells. HepG2 cells cultured in the presence or absence of either PMA or resveratrol at indicated concentrations were placed in the upper well. Invasiveness of the cells was determined by measuring the ability to pass through a layer of matrigel-coated filter. After $24 \mathrm{~h}$, cells on the underside side of the filter were fixed, stained and counted as described under Materials and methods section. Data represented the mean $\pm \mathrm{SD}$ of at least three independent experiments ${ }^{\mathrm{d}} \mathrm{p}<0.05 \mathrm{vs} \mathrm{c}$

resveratrol treated group ( $18.48 \%$ inhibition) compared with the normal saline-treated group. A $42.48 \%$ inhibition of tumor growth in the $100 \mathrm{mg} \mathrm{kg}^{-1}$ resveratrol treated group was observed compared with the normal salinetreated group. However, body weight in the resveratroltreated groups was not reduced significantly compared with the normal saline-treated group.

Inhibitory effect of resveratrol on liver metastasis: Liver metastasis was observed in 8 mice from the control group, whereas 5 mice showed liver metastasis in the $50 \mathrm{mg} \mathrm{kg}^{-1}$ group and 1 in the $100 \mathrm{mg} \mathrm{kg}^{-1}$ group. A suppressive effect of the subcutaneous administration of $100 \mathrm{mg} \mathrm{kg}^{-1}$ resveratrol on liver metastasis was significantly demonstrated when compared with the control group $(\mathrm{p}<0.01)$ but $50 \mathrm{mg} \mathrm{kg}^{-1}$ has no significant difference $\left(\mathrm{p}<0.05\right.$ ). Subcutaneous administrations of $100 \mathrm{mg} \mathrm{kg}^{-1}$ resveratrol clearly decreased the number of metastasis in the liver (Table 2).

Inhibitory effect of resveratrol on MMP-9 $\mathrm{mRNA}$ induced by PMA: The treatment of HepG2 cells with resveratrol induced a decrease in the levels of PMA-stimulated MMP-9 mRNA. PMA induced the expression and secretion of large amounts of latent MMP-9 as determined
Table 1: Effect of resveratrol on growth of HepG2 tumor xenografts in nude

\begin{tabular}{|c|c|c|c|c|}
\hline \multirow[b]{2}{*}{ Treatments } & \multirow[b]{2}{*}{$\mathrm{n}$} & \multicolumn{3}{|c|}{ Inhibition of tumor growth } \\
\hline & & $\begin{array}{c}\text { Tumor volume } \\
\left(\mathrm{mm}^{3}\right)(\%)\end{array}$ & $\begin{array}{l}\text { Inhibition } \\
\text { ratios (\%) }\end{array}$ & $\begin{array}{c}\text { Body } \\
\text { weight (g) }\end{array}$ \\
\hline Normal saline $(0.9 \%)$ & 10 & $303.64 \pm 13.07$ & - & $19.35 \pm 0.35$ \\
\hline $50 \mathrm{mg} \mathrm{kg}^{-1} \mathrm{Res}$ & 10 & $247.54 \pm 11.80^{\mathrm{a}}$ & 24.68 & $17.70 \pm 1.13$ \\
\hline $100 \mathrm{mg} \mathrm{kg}^{-1}$ Res & 10 & $174.66 \pm 12.73$ & 51.54 & $21.70 \pm 0.99$ \\
\hline
\end{tabular}

${ }_{\mathrm{a}} \mathrm{p}<0.05$ vs control

Table 2: Inhibitory effect of resveratrol on liver metastasis

\begin{tabular}{lcc}
\hline & \multicolumn{3}{c}{ Inhibition of liver metastasis } \\
& Number of mice & Metastasis ratios (\%) \\
\hline Treatments & 8 & 80 \\
Normal saline $(0.9 \%)$ & 5 & $50^{\mathrm{a}}$ \\
$50 \mathrm{mg} \mathrm{kg}^{-1}$ Res & 1 & $10^{\mathrm{b}}$ \\
$100 \mathrm{mg} \mathrm{kg}^{-1}$ Res & &
\end{tabular}

by Reverse Transcription-PCR (RT-PCR). As shown in Fig. 4, the steady-state MMP-9mRNA levels were lower in resveratrol-treated cells compared with cells not treated with resveratrol $(\mathrm{p}<0.05)$. MMP-9 mRNA was decreased by resveratrol in a dose-dependent manner.

Inhibitory effect of resveratrol on MMP-9 protein: Expression of MMP-9 protein was identified by Western blot analysis. As shown in Fig. 5, resveratrol dramatically inhibited the expression of MMP-9 protein in a 
(a)

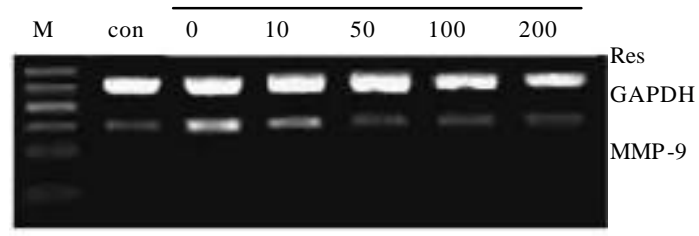

(b)

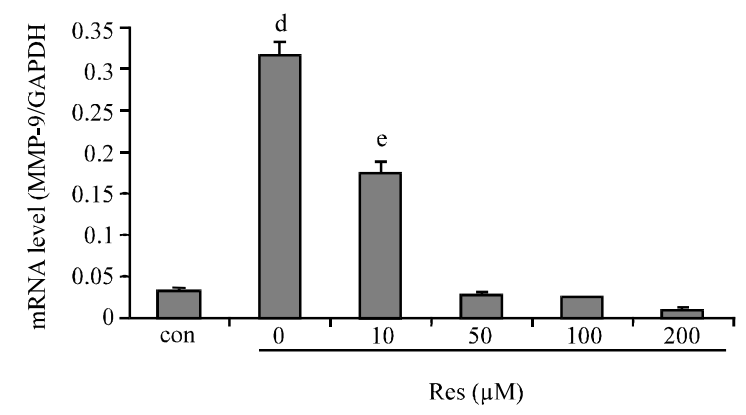

Fig. 4: Inhibition of resveratrol on expression of MMP-9 mRNA in HepG2 cells exposed to $200 \mathrm{nMPMA}$ for $24 \mathrm{~h}$, a) HepG2 cells were treated with different concentrations of resveratrol in the presence of 200 nMPMA. TotalRNA was isolated and RT-PCR analysis was performed, b) The mRNA levels were represented by the ratio of net density of MMP-9 and GAPDH. The MMP-9 levels shown are representative of three independent experiments. ${ }^{\mathrm{d}} \mathrm{p}<0.01$ vs con ${ }^{\mathrm{e}} \mathrm{p}<0.05$ vs $\mathrm{d}$
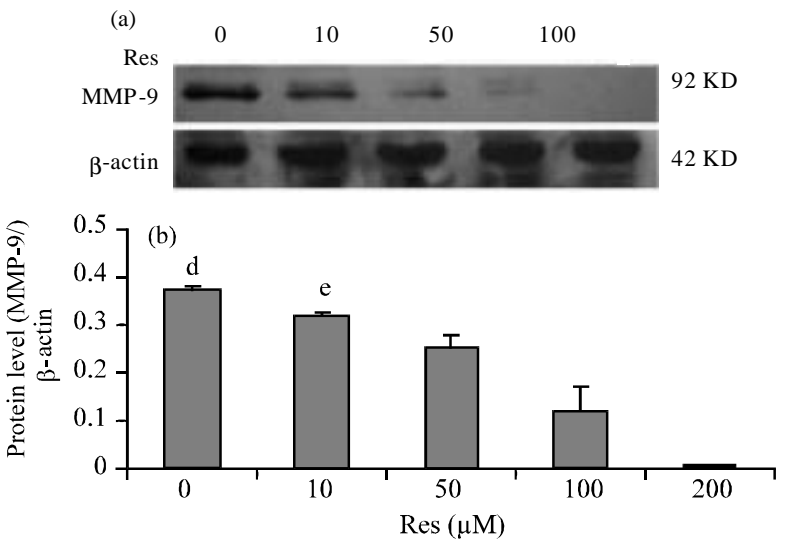

Fig. 5: Inhibition of resveratrol on expression of MMP-9 protein in HepG2 cells exposed to 200 nMPMA for 24 h, (a) HepG2 cells were treated with different concentrations of resveratrol in the presence of 200 nMPMA. Western blot analysis was performed and (b) The protein levels were represented by the ratio of net density of MMP-9 and $\beta$-actin. The MMP-9 protein levels shown are representative of three independent experiments ${ }^{\mathrm{e}} \mathrm{p}<0.05$ vs d

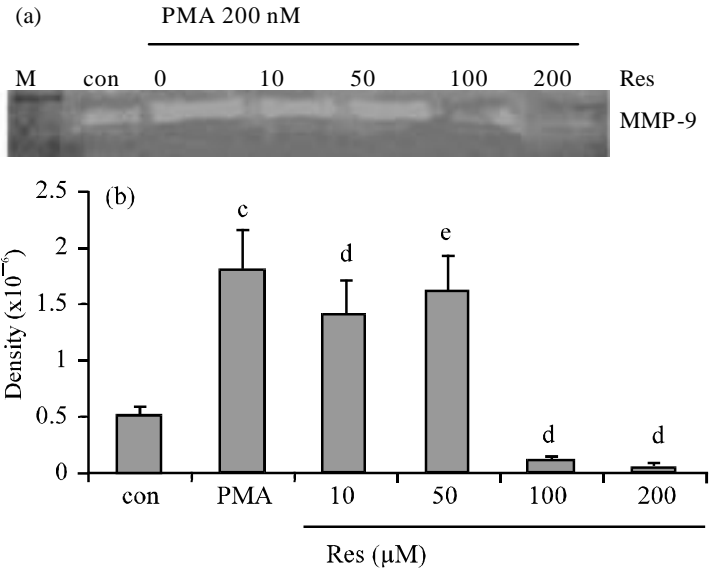

Fig. 6: Inhibition of resveratrol on activity of MMP-9 in HepG2 cells exposed to 200 nMPMA for $24 \mathrm{~h}$. HepG2 cells were treated with different concentrations of resveratrol in the presence of 200 nMPMA. Gelatin zymography was performed. The MMP-9 activity levels shown are representative of three independent experiments. ${ }^{c} \mathrm{p}<0.05$ vs con, ${ }^{\mathrm{d}} \mathrm{p}<0.05$ vs PMA

dose-dependent manner. These results showed that resveratrol inhibited the MMP-9 protein secreted from HepG2 cells via induction by PMA.

Inhibitory effect of resveratrol on MMP-9 enzyme activity: Effect of resveratrol on MMP-9 enzyme activity was evidenced by gelatin zymography. As shown in Fig. 6, resveratrol dramatically inhibited the proteolytic activity of MMP-9 in a dose-dependent manner $(p<0.05)$. These results show that resveratrol inhibit the enzymatic activity of the MMP-9 protein secreted from HepG2 cells via induction by PMA.

Inhibition of transcriptional activity of MMP-9 gene through suppression of PMA-stimulated NF-kappa B activity by resveratrol: We examined the effect of resveratrol on NF-kappa B expression by Electrophoretic Mobility Shift Assay (EMSA). PMA induced binding of NF-kappa B in HepG2 cells. Resveratrol significantly inhibited NF-kappa B DNA-binding activity in a dosedependent manner and NF-kappa B was decreased by IkappaBalpha an NF-kappa B-specific inhibitor. The results suggested therefore that resveratrol inhibited transactivation DNA binding of NF-kappa B (Fig. 7).

Hepatic carcinoma is one of worldwide malignant tumor and 110 thousands people die of it every year, its death rate is second of all tumor. Invasion and metastasis is main physiologic barrier. Tumor invasion and metastasis are a multistepped and complex process that includes cell division and proliferation, proteolytic 


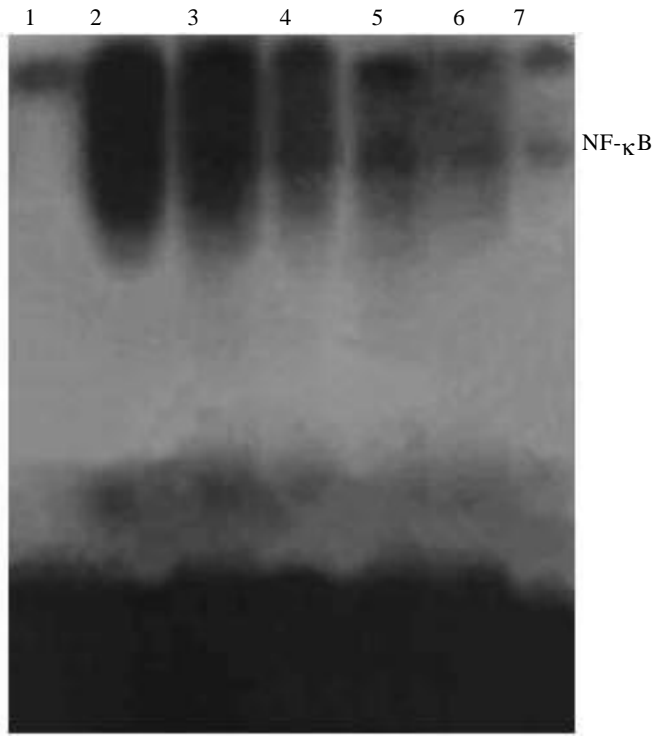

Fig. 7: Suppression of PMA-induced NF- $\mathrm{KB}$ activation by resveratrol. HepG2 cells were treated with different concentration of resveratrol in the presence of 200 nM PMA. After $24 \mathrm{~h}$, the cell nuclear extracts were prepared and incubated with the radiolabelled oligonucleotides containing NF- $\mathrm{kB}$ consensus sequence for analysis by EMSA. Lane 1, free probe alone (no nuclear extracts); Lane 2, $200 \mathrm{nM}$ PMA; Lane 3, $200 \mathrm{nM}$ PMA+10 $\mu$ M Res; Lane 4, $200 \mathrm{nM}$ $\mathrm{PMA}+50 \mu \mathrm{M}$ Res; Lane 5, $200 \mathrm{nM}$ PMA $+100 \mu \mathrm{M}$ Res; Lane 6, $200 \mathrm{nM}$ PMA+200 $\mu \mathrm{M}$ Res; Lane 7, 200 nM PMA+ IkappaBalpha

digestion of the ECM, cell migration through the basement membranes to reach the circulation system and the remigration and growth of tumors at metastatic sites (Hidalgo and Eckhardt, 2001). MMPs plays a major role in promoting angiogenesis and tumor metastasis (Stetler-Stevenson, 1999). An hanced expression of MMP-9 has been shown to be associated with the progression and invasion of tumors (Cho et al., 2006; Yamamoto et al., 2004). Over expression of MMP-9 associated with the capsular infiltration of $\mathrm{HCC}$ and growth of small HCC has been reported (Arii et al., 1996; Sakamoto et al., 2000). On the basis of above-mentioned studies, MMP-9 inhibitors wiil be wide used in hepatoma therapy. Although, many broad-spectrum MMP-9 inhibitors can be clinically applicable, the above drugs are generally known to have strong cellular cytotoxicity and side effects such as myalgia, stiffness and edema. Thus, strong MMP-9 inhibitor without any cytotoxicity and side effects would be highly desirable. Resveratrol itself induces apoptosis via the mitochondrial pathway and can sensitize cells to ligand-induced, death receptor mediated apoptosis (Pohland et al., 2006). As shown in the present experiments that resveratrol inhibited growth of HepG2 cells with a dose and time-dependent manner. The reduced cell viability is due to apoptosis or proliferation inhibited by resveratrol. Invasion assay found that resveratrol induce a decrease in the potential for invasion. Subcutaneous administrations of resveratrol clearly decreased the growth and metastasis of liver transplantation tumor in nude mice. It has been shown that different agents including growth factors such as epidermal growth factor, platelet-derived growth factor, transforming growth factor and inflammatory cytokines such as TNF and IL-1 modulate the expression of the MMP-9 gene (Lee et al., 2000).

In previous investigation, the inhibited effect of resveratrol on hepatocellular carcinoma cells contributed partly to suppression of MMP-9 expression. In order to find the mechanism, resveratrol was found to suppress PMA-mediated activation of MMP-9 in HepG2 cells. PMA, a well-known selective activator of protein kinase-C has been shown to enhance the production of MMP-9 through the activation of transcription factors such as $\mathrm{NF}-\mathrm{kB}$ and AP-1 (Shin et al., 2007). MMP-9 activity increased markedly with exposure to PMA in the study. It was showed in the present experiments that resveratrol suppressed PMA-mediated induction of MMP-9 activity by inhibiting MMP-9 gene transcription and have dose dependent. Resveratrol was also found to have conspicuous inhibitory effect on MMP-9 enzyme activity. So resveratrol may be MMP-9 inhibitor and suppress invasion and metastasis of HepG2 cells. All of above research suggest that resveratrol could down regulate invasion and metastasis via inhibiting MMP-9 expression of HepG2 cells. In order to the mechanism by which resveratrol modulates MMP-9 gene expression, resveratrol was found to suppress PMA-mediated activation of NF-kappa B in HepG2 cell. It is known that the human MMP-9 promoter contains cis-acting regulatory elements and transcription factors, including AP-1 and NF-kappa B which participate in the regulation of the MMP-9 gene (Bond et al., 1998). In the study, expression of NF-kappa B was decreased with concentration depression of resveratrol. Furthermore, depression of NF-kappa B and MMP-9 have positive correlation. This effect is likely to contribute to the MMP-9 inhibition activity of resveratrol via NF-kappa B.

\section{CONCLUSION}

In conclusion, it has shown that resveratrol could inhibit PMA-induced MMP-9 expression of HepG2 cell. This inhibition may be mediated by the regulation of NFkappa B. Future study will investigate the effects of resveratrol in vivo in control of hepatocellular carcinoma cell in clinics. 


\section{REFERENCES}

Adithi, M., V. Nalini, M. Kandalam and S. Krishnakumar, 2007. Expression of matrix metalloproteinases and their inhibitors in retinoblastoma. J. Pediat. Hematol. Oncol., 29: 399-405.

Arii, S., M. Mise, T. Harada, M. Furutani and S. Ishigami et al., 1996. Overexpression of matrix metalloproteinase 9 gene in hepatocellular carcinoma with invasive potential. Hepatology, 24: 316-322.

Bond, M., R.P. Fabunmi, A.H. Baker and A.C. Newby, 1998. Synergistic upregulation of metalloproteinase-9 by growth factors and inflammatory cytokines: An absolute requirement for transcription factor NFkappa B. FEBS Lett., 435: 29-34.

Cho, K., T. Tajiri, T. Ishiwata, E. Uchida and T. Aimoto, 2006. Keratinocyte growth factor and its receptor correlate with venous invasion via matrix metalloproteinase-9(MMP-9) in pancreatic cancer. Pancreas, 33: 452-452.

Ferguson, L.R., 2001. Role of plant polyphenols in genomic stability. Mutat. Res., 475: 89-111.

Gunther, S., C. Ruhe, M.G. Derikito, G. Bose, H. Sauer and M. Wartenberg, 2007. Polyphenols prevent cell shedding from mouse mammary cancer spheroids and inhibit cancer cell invasion in confrontation cultures derived from embryonic stem cells. Cancer Lett., 250: 25-35.

Hidalgo, M. and S.G. Eckhardt, 2001. Development of matrix metalloproteinase inhibitors in cancer therapy. J. Natl. Cancer Inst., 93: 178-193.

Jang, M., L. Cai, G.O. Udeani, K.V. Slowing and C.F. Thomas et al., 1997. Cancer chemopreventive activity of resveratrol, a natural product derived from grapes. Science, 275: 218-220.

Kader, A.K., J. Liu, L. Shao, C.P. Dinney and J. Lin et al., 2007. Matrix metalloproteinase polymorphisms are associated with bladder cancer invasiveness. Clin. Cancer Res., 13: 2614-2620.

Lee, P.P.H., J.J. Hwang, G. Murphy and M.M. Ip, 2000. Functional significance of MMP-9 in tumor necrosis factor-induced proliferation and branching morphogenesis of mammary epithelial cells. Endocrinology, 141: 3764-3773.

Mediero, J.M.G., A.F. Alonso, A.P. Borda, M.L. Galan, J.A. Cuesta, V.C. Robles and A.B. Sanchez, 2005. Effect of polyphenols from the Mediterranean diet on proliferation and mediators of in vitro invasiveness of the MB-49 murine bladder cancer cell line. Actas Urol. Esp., 29: 743-749.
Middleton, Jr. E., C. Kandaswami and T.C. Theoharides, 2000. The effects of plant flavonoids on mammalian cells: Implications for inflammation, heart disease and cancer. Pharmacol. Rev., 52: 673-751.

Pohland, T., S. Wagner, M. Mahyar-Roemer and K. Roemer, 2006. Bax and Bak are the critical complementary effectors of colorectal cancer cell apoptosis by chemopreventive resveratrol. Anticancer Drugs, 17: 471-478.

Pozo-Guisado, E., J.M. Merino, S. Mulero-Navarro, M.J. Lorenzo-Benayas, F. Centeno, A. AlvarezBarrientos and P.M. Fernandez-Salguero, 2005. Resveratrol-induced apoptosis in MCF-7 human breast cancer cells involves a caspase-independent mechanism with downregulation of $\mathrm{Bcl}-2$ and NF-kappa B. Int. J. Cancer, 115: 74-84.

Sakamoto, Y., K. Mafune, M. Mori, T. Shiraishi and H. Imamura, 2000. Overexpression of MMP-9 correlates with growth of small hepatocellular carcinoma. Int. J. Oncol., 17: 237-243.

Shin, Y., S.H. Yoon, E.Y. Choe, S.H. Cho, C.H. Woo, J.Y. Rho and J.H. Kim, 2007. PMA-induced upregulation of MMP-9 is regulated by a PKCalpha-NFkappaB cascade in human lung epithelial cells. Exp. Mol. Med., 39: 97-105.

Stetler-Stevenson, W.G., 1999. Matrix metalloproteinases in angiogenesis: A moving target for therapeutic intervention. J. Clin. Invest., 103: 1237-1241.

Sun, C.Y., Y. Hu, T. Guo, H.F. Wang, X.P. Zhang, W.J. He and $H$. Tan, 2006. Resveratrol as a novel agent for treatment of multiple myeloma with matrix metalloproteinase inhibitory activity. Acta Pharmacol. Sin., 27: 1447-1452.

Vaslamatzis, M.M., C.D. Petraki and A. Papathoma et al., 2002. Matrix metalloproteinases MMP -2 and MMP-9 as prognostic markers in urothelial carcinoma. J. Ann. Oncol., 10: 18-22.

Vlodavsky, I. and Y. Friedmann, 2001. Molecular properties and involvement of heparanase in cancer metastasis and angiogenesis. J. Clin. Invest., 108: 341-347.

Yamamoto, H., A. Vinitketkumnuen, Y. Adachi, H. Taniguchi and T. Hirata, 2004. Association of matrilysin-2 (MMP-26) expression with tumor progression and activation of MMP-9 in esophageal squamous cell carcinoma. Carcinogenesis, 25: 2353-2366. 